\title{
Analysing the causes of Environmental Management and Audit Scheme (EMAS) decrease in Europe
}

\begin{abstract}
Environmental Management and Audit Scheme (EMAS) is the most important public standard for Environmental Management System. In the last few years the number of certified organisations has been decreasing. Scholars have largely debated on the drivers, barriers, and benefits of, but the recent decrease in EMAS registrations has not been sufficiently studied, leaving unsolved questions for scholars, practitioners and policy makers. This paper aims to address this literature gap by i) analysing the trends of other voluntary certification schemes in order to understand whether the decrease is a peculiarity of EMAS; ii) investigating the reasons why formerly registered organisations have abandoned EMAS and why ISO14001 certified organisations do not adopt EMAS. The paper reports results of 17 interviews highlighting the lack of financial and human resources, the lack of market and stakeholder recognition, and the unclear added value of EMAS as reasons for the decrease of EMAS.
\end{abstract}

Keywords: EMAS abandonment, drop out factors, EMAS decrease, Environmental Management Systems, ISO14001

\section{Introduction}

In the last few years, the voluntary environmental management initiatives undertaken by organisations have gained increasing importance both in public policies and corporate strategies. At a worldwide level, there are many certification schemes that private organisations can adhere to in order to obtain public recognition of their voluntary commitment to environmental improvements. The most widespread and renowned schemes for environmental management systems are ISO 14001 and the Environmental Management and Audit Scheme (EMAS) (Heras - Saizarbitoria et al., 2015b; Stevens et al., 2012).

The EMAS scheme was launched in 1993 with the EC Regulation 1836 (Bracke and Albrecht, 2007) and was later revised in 2001 and 2009. Currently, the Regulation is undergoing its third revision process and the fourth version of EMAS is expected in late 2017. Organisations from all economic sectors can implement EMAS. The third version issued in 2009 extended its scope to non-EU countries, although it is still almost exclusively applied in EU Member States (Testa et al., 2014). Currently (April 2017), 3,963 organisations and more than 9,202 sites in Europe have committed to EMAS, however in the last 2-3 years, according to the official data of the European EMAS Helpdesk, the numbers of EMAS registered organisations has started a slow descending trend.

ISO 14001 is an international private standard managed by the International Organization for Standardization (ISO) launched in 1996, and since 2001 EMAS adopted it as the reference concerning its environmental management system. Indeed, the revised EMAS Regulation n. 761/2001 integrated the international environmental management systems based on ISO 14001. The standard has been 
recently revised and the new ISO14001:2015 must be implemented by all certified organisations by September 2018.

Over the last 20 years, scholars have investigated EMAS and ISO14001 from several perspectives such as: the drivers leading to their adoption, the benefits, the contribution to competitiveness, and the effects on environmental performance. However the recent considerable decrease in the number of EMAS registered organisations has not yet been widely investigated. This current negative trend has raised many unsolved questions among scholars, practitioners and policy makers. In addition also looking to the literature contributes on EMAS barriers, this term is referred mainly the barriers to the adoption of the standard and not to the reasons of the abandonment of the certification.

This paper aims to contribute to bridging this gap by describing the results of interviews involving several EU companies. In addition, in order to better frame the objectives of our paper, this study wants to add a new term in the Environmental Management System (EMS) literature: "drop out factors". "Drop out factors" are the reasons that press the organisations and that cause the decision to drop out of environmental certification. As mentioned above, these are different from EMS barriers, since they are referred to the reasons that impede to adopt a certification.

The paper is structured as follows. Section 2 outlines the theoretical framework and the research questions of the study. Section 3 presents the method adopted in the research. Section 4 illustrates the results and Section 5 provides the concluding remarks.

\section{Theoretical background and research questions}

The aim of Environmental Management Systems (EMSs) is to develop, implement, manage and monitor the environmental activities of organizations (Sayre, 1996; Melnyk et al., 2003). They are classified from a policy perspective as voluntary tools. At an international level there are three categories of environmental policy tools: direct regulations, economic instruments, and soft or voluntary instruments (Testa et al., 2011; Barde, 1995, Daddi et al., 2016a). Direct regulations (also called command and control instruments) are based on binding obligations. Regulatory instruments are compulsory for organisations that have to comply with specific environmental emission limits. Different forms of environmental regulations may have different impacts on a firm's performance (Testa et al. 2014) and competitiveness (Testa et al., 2011, Daddi et al., 2014). Economic instruments are based on environmental duties (e.g. taxes and charges, subsidies), tradable permits and environmental liability, and basically rely on the "polluter pays principle" (Hawkins, 2000). Soft instruments include voluntary tools such as, for example, environmental certification schemes. Both EMAS and ISO 14001 are voluntary policy tools that require organisations to implement certain rules and procedures to monitor environmental aspects and to improve their performance (Hillary, 2004; Testa et al., 2014).

By adopting an environmental certification (i.e. by participating in one of these voluntary schemes) firms decide voluntarily to improve their environmental performance beyond the legal requirements (Daddi et al., 2015). In doing so, they are driven by various motivating factors, and the reasons why organizations specifically adopt EMAS have been explored by some authors. For example, Neugebauer (2012) found that the implementation of EMAS in German automotive and engineering industries is mainly influenced by internal drivers which is also supported by other studies (Boiral, 2011; Grolleau et al., 2007; Heras-Saizarbitoria et al., 2015). Other factors are also important for companies to implement EMAS, such as pressure for greater external legitimacy (Darnall et al., 2008a) or pressure from local communities (Maiello et al., 2011; Daddi et al., 2011b).

The benefits of EMAS implementation can be another strong driver. Iraldo et. al., (2009) highlighted that the main positive aspect from the adoption of EMAS is the management of legal compliance. Other benefits include resource savings (Vernon et al., 2009), such as energy and materials (UBA and BMU, 2013), but also the administrative simplification for certified companies (Daddi et al., 2014; Testa et al., 2016). Some studies have confirmed the benefits of EMAS on environmental 
performance (Testa et al., 2014; Daddi et al., 2011a) although some authors highlighted that the likelihood of improvement depends on the degree of EMAS implementation (Darnall et al., 2008b). Finally some studies have highlighted the potential of EMAS to improve management and performance of territorial areas (Daddi et al., 2010; Daddi and Iraldo, 2016).

From a wider perspective, many studies have investigated the diffusion rate of the main environmental management standards. For example, Marimon et al. (2011), investigated whether there were diffusion patterns of ISO 14001 in different sectors. and found that it was homogenous among sectors. In contrast, Heras-Saizarbitoria et al., (2015a) explored the diffusion of EMAS across several economic sectors in EU Member States, and found that the number of certifications was higher in more polluting sectors and that the diffusion changes among different states. Daddi et al. (2015), focused on the country diffusion of ISO14001 comparing plurennial trends with the trends of macro-economic and development indexes. They found positive relations between ISO certifications and some economic indexes, while the positive relation was not confirmed in the case of development indexes.

Other studies focus on the number of registrations, such as Neugebauer (2012). This author reported that already in 2008, a higher number of companies and organisations were participating in ISO 14001 than in EMAS. In fact, according to the International Organisation for Standardization in Europe, ISO 14001 is adopted more than EMAS (ISO 2013). Why the ISO 14001 standard has always been more "popular" than EMAS, is explained by Neugebauer, by external pressures. In other words, the institutional environment plays an importance role in the case of ISO 14001. In contrast, Neugebauer (2012) did not find that the institutional environment was important for the EMAS adoption.

Daddi et al. (2016b) studied the relation between institutional pressures and the EMAS adoption and effectiveness. Based on a large sample of EMAS registered organizations the authors found that the performance of EMS was associated with different kinds of institutional pressures. Testa et al. (2015) found that institutional pressures strengthen EMAS adoption, although the real integration or superficial adoption of environmental practices depended on the kind of stakeholder involved.

Bracke and Albrecht (2007) highlighted that ISO 14001 certifications outnumber the EMAS registered organisations but the speed at which and the extent to which ISO 14001 has outnumbered EMAS differs between European countries, with Austria, Germany, Italy and Spain having the highest number.

However, only in 2001 and 2002, respectively, Germany and Austria registered a high number of ISO 14001 with respect to EMAS organisations. In other EU countries, ISO 14001 has always been dominant, or, in some cases the adoption rate of ISO 14001 has varied between countries, as shown by Prakash and Potosky (2006). For example, Casadeus et al. (2008) investigated the diffusion of ISO 14001 at the global level. They considered 13 countries for the period 1995-2005. The study forecast that the maximum number of ISO 14001 certifications would be 160,000, but this has since turned out to be a considerable underestimation. Similarly, some authors (Lagodimos et al., 2007) have studied the diffusion of ISO 14001 at a country-level. The authors investigated ISO 14001 adoption in Greece and showed that the certification was more popular in the manufacturing sector than in services and commerce.

While it is commonly known that EMAS numbers have been decreasing over the last few years, it is not clear whether this negative trend is also common to other voluntary certification standards, thus:

RQ1: can the decrease/stagnation of EMAS registrations be observed in other voluntary certification standards?

Several authors have studied the dynamics and barriers in EMAS adoption while only few studies focused on EMAS drop out factors.. Barriers can be classified in internal, if are referred to internal dynamics within organizations; or in external, if they are related to external aspects with respect to companies (Merli et al., 2016; Hillary, 2004). Typical internal barriers include for example lack of 
internal resources as human and/or financial, while external barriers refer to constraints about institutional frameworks, aspects related to the market or to the customers.

For example, the high costs involved in the registration (Salomone, 2008; Northern Ireland Environmental Agency, 2009), especially for SMEs companies, and the lack of an internal commitment from the organization (Lozano and Vallés, 2007; Bist, 2007; Iraldo et al. 2006) can represent significant internal barriers to the adoption of environmental management systems. External barriers to EMAS, are the lack of market recognition of the scheme and the lack of support from institutions (Merli et al., 2016), including also low incentives and low simplifications provided to EMAS firms.

However, few scholars have investigated the barriers experienced by an organisation that has already been EMAS registered which could lead to the abandonment of the environmental certification i.e. what we defined in these paper as "drop out factors". Among them there are some authors have explored why organizations have not renewed the certification or have withdrawn from EMAS. The study of Von Ahsen at al., 2004 for example was based on interviews with organizations that decided to not renew their adhesion to EMAS scheme. Among studies exploring reasons of EMAS withdrawn there is the one of Vernon et al. (2009). Authors found that among main reasons of the withdrawal there were unclear or insufficient EMAS benefits that justify the certification, followed by the competition of EMAS with other environmental management systems. The study of Iraldo et al. (2006) found that the perception that there is no EMAS added value with respect to ISO 14001 was a key element explaining why some organizations dropped out of EMAS.

The decline in the number of certified companies is defined by the literature on environmental management as decertification (Sampaio et al., 2013; Bernardo et al., 2015). Decertification means that a company can decide to not achieve the renew of their environmental certification or that fewer new certifications are issued to organizations (Heras - Saizarbitoria et al., 2015b). Preziosi et al., (2016) observed that the decrease of EMAS is mainly due to the decrease in the new annual registration rate and the lack of renewals. The authors identified as main drop out factor in Italy the lack of human and financial resources.

As highlighted, there are numerous studies on barriers to the first adoption of EMAS, however the decrease in EMAS numbers and more specifically EMAS drop out factors still need clarification, thus:

\section{RQ2: What are the reasons for the decrease/stagnation of EMAS?}

We aim to answer this research question by exploring two different research avenues: the drop out factors of EMAS by formerly registered organisations:

\section{RQ2.1: Why do registered organisations withdraw from EMAS?}

The second aspect we aim to investigate is why ISO14001 certified organisations also decide not to adopt EMAS. The number of ISO14001 registrations in Europe is very high compared to EMAS registrations. A large majority of EMAS organisations are also ISO 14001 certified, which is usually seen as an intermediate step to achieving EMAS (Testa et al., 2014). Thus, a second sub-research question is:

\section{RQ2.2: Why do ISO14001 certified organisations not adopt EMAS?}

Figure 1 summarizes the research questions. 


\section{Figure 1. Research questions of the study}

\section{Method}

The methods adopted in this paper are qualitative, including desk research to answer RQ1, and content analysis (Weber RP., 1990) of interview reports to answer RQ2.

For the first research question, we collected data on the number of different environmental certifications related to the years 2010-2015. We crossed checked the EMAS numbers with another two voluntary schemes: ISO14001 and the Forest Stewardship Council (FSC). We used these environmental schemes as a comparison with EMAS because both are international standards, both are voluntary, and a high number of certificates have been issued. The comparison between EMAS, ISO14001 and FSC trends refers to the European Union, given that EMAS is almost exclusive to Europe. In addition, although the FSC certification does not really fit in with the adoption of ISO14001 and EMAS, it helped us to understand whether the decrease only applies to process certifications (such as EMAS and ISO14001) or also involves voluntary product certifications (as FSC is). In other words, despite FSC is a specific tool for wood and related products, from a methodological point of view it has been selected as voluntary certification in order to sample the trend also in product certification. It has been considered as a sort of control variable to verify if the decrease can be considered a peculiarity of process certification or it is also present in relevant product certifications.

To answer the second research question and sub-questions, we used data collected during the interviews of the EMAS Evaluation Study (Weiss et al., 2015). This is a service contract assigned by the European Commission in 2015 to assess the efficacy of EMAS and to collect data and information to update it - our research group was directly involved in this assessment. We used in-depth interviews (Burnard, 1994; Ryan et al., 2009) and content analysis (Weber RP, 1990) given that these are the primary methods used in qualitative research.

According to this approach, the interview is often seen as one of the most important ways to "enter into the other person's perspective" (Patton, 2002, p. 341).

We conducted 38 in-depth interviews with European organisations in the period from May to July 2014. In line with our research questions, we interviewed two different kinds of organisations. The first group included organisations that were EMAS-certified but who had decided to abandon the scheme. We used this sample to investigated the EMAS drop out factors. The second group included companies that had been ISO14001-certified for several years and had decided not to register with EMAS.

To select the first group, we consulted the EU EMAS Register. In particular comparing the different yearly updated of the Register in the period 2010-2015 we identified the organisations that dropped out from EMAS since in a specific year they were listed in the Register but in the following years they were not more included. Regarding the selection of ISO14001 certified companies, we consulted the database of the accreditation bodies selecting companies that were environmentally certified for at least 5 years.

In this kind of interview respondents can also offer their own insights (Yin, 2009). We thus asked interviewees to give their opinions on the abandonment of the certification and the difficulties they faced. The data collection was performed on the basis of a standardized protocol, which we also provided to companies before the interview. 
We defined a standardized protocol to use for all the interviews. Interviews lasted about one hour each and were conducted face-to-face according to the suggestions in the literature (Seidman, 1998, Patton, 2002) and they have been carried out in English, German, Italian and Spanish languages. The interviews were related to several aspects of the certification experience and not only to the reasons for the abandonment. Further email exchanges enabled us to clarify and enrich some aspects. The first group was composed of organisations that were EMAS-certified but who had decided to abandon the environmental registration in the last years. The second group were companies that had been ISO14001-certified for several years and had decided not to register with EMAS. In the data analysis, we identified 17 usable interviews out of the 38 interviewed that provided useful answers for the aims this study, since the interview protocol was related also to other topics. The selected interviews were 10 related to former EMAS organisations while 7 linked with ISO14001 companies that did not decide to adopt EMAS. Additional characteristics of the 17 organisations are summarized in the Table 1 .

\section{TABLE 1 ABOUT HERE}

The sample highlights a higher representativeness of German, Italian and Spanish organisations that are also the Countries with higher numbers of EMAS registered companies.

\section{Results}

\subsection{Comparing EMAS with ISO14001 and Forest Stewardship Council (FSC) trends}

To collect data on the number of registrations over the considered period, we used the official data diffused by the management body of the three environmental schemes. We processed this information because for FSC and ISO 14001 the number of registrations was not available at an aggregated level for the European Union, but only at the Member State level or at European level that (in this latter case there are also a number of non-EU Member States). This enabled us to take into account that some European Member States joined the EU after 2005 (the first year of interest for our study). The sources of data were the official EMAS register kept by the European Commission for EMAS, the data published by ISO on its website (www.iso.org) for ISO14001, and direct contact and related email exchanges with the management body of the FSC standard. For FSC, only the data related to the chain of custody certifications were considered. The other FSC certification i.e. forest certification was deemed unsuitable as a comparative variable with respect to EMAS and ISO14001.

The number of EMAS registrations has increased since the beginning of its application in the EU (1995). According to the data of the EC EMAS register, there were approximately 2000 EMAS organisations in 1997. This figure steadily increased up to 2001, reaching more than 3900 registrations. From 2001 to 2004 the numbers were stable. From 2004 to 2010 the number increased again, reaching a peak of more than 4500 registered organisations. However, from the end of 2010 registrations started to decrease. In 2015 there were 3928 certified organisations (EU EMAS Register; German EMAS register, 2016), and the last available updated data of April 2017 refers to 3963 EMAS organisations (European EMAS Helpdesk, 2017).

Since 1996, when ISO 14001 was first published, this standard has become increasingly common. In 2015, the total number of ISO 14001 certificates worldwide was 319,324, more than 119,000 of them were issued in the EU. The countries with the highest number of certificates in 2015 were China, Japan, Spain, Italy and United Kingdom (ISO, 2015). 
The Forest Stewardship Council (FSC) is an international environmental standard that is becoming even more important due to the high number of products certified. FSC was introduced in 1994 by an independent non-profit organization whose aim was to promote 'an environmentally appropriate, socially beneficial and economically viable management' of forests, as stated in the Forest Stewardship Council's mission. There are two different kinds of FSC certification: the Forest Management and the Chain of Custody certification. The FSC chain of custody certification is very diffuse, in 201531.191 certificates were issued in 120 countries. In 2015 the leaders were the United States and China, with about 2800 and 4600 certifications, respectively. In the same year in Europe there were around 14000 certifications. The United Kingdom, Germany and Italy had the highest number of certificates. In Brazil and Japan the FSC scheme is also very popular (FSC, 2015a).

The trends were calculated considering 2010 as the starting year. The yearly percentage of variations in the number of certifications was compared with this baseline.

\section{FIGURE 2 ABOUT HERE}

Figure 2. Certifications trends in the period 2010-2015 for EMAS, ISO 14001 and FSC environmental schemes.

* Source of data: our elaboration on the basis of official data of the schemes' management bodies (ISO 14001: ISO, 2015; FSC: www.fsc.org; EMAS: EU EMAS Register; German EMAS register).

Figure 2 reveals that EMAS is the only certification scheme with the lower number compared to 2010 level. The decrease in the number of EMAS registrations with respect to 2010 started in 2011 and continued to a large extent throughout the period considered. ISO 14001 in 2015 was around $14.1 \%$ above the 2010 level although there was a slight decline only in 2011. FSC certifications had a strong growth for all the periods considered: in 2015 the growth percentage of the number of certifications was $+83.43 \%$ with respect to 2010 .

The figure indicates that the trends of the three different certification schemes are very different. To answer our first RQ, the findings highlight that the decrease is a phenomenon only related to EMAS. Comparing the EMAS trend with ISO14001 (which is the standard closest in terms of requirements and aims to EMAS), this is particularly clear. In addition, FSC has shown a very high growth in Europe. Verifying the EMAS numbers of each Member States is possible highlights that EMAS decreases particularly in Germany and Spain while in Italy it seems to have a stable trend. Considering the Countries with a lower number of EMAS registrations a negative trend could be also observed Denmark, Greece, and Portugal. Unfortunately, data referred to the industries that have registered the higher number of abandonments are not available.

The possible reasons for this increasing focus on FSC are first that virgin wood products face increasing competitiveness from recycled wood materials. The FSC certification indicates the sustainable management of virgin wood, which could be seen by the producers of virgin wood products as a tool to deal with competitors that use recycled wood. Second, the organisations that want to manage to their business in a sustainable way are increasingly acting "outside of their gates". The increased application of tools based on a life cycle perspective such as PEF (Product Environmental Footprint), the new requirements of ISO14001:2015 on Life Cycle Assessments, the increasing application extended producer responsibility as the key principle of several environmental regulations are contributing to a more sustainable management of the entire supply chain by European organisations. Thus, the FSC chain of custody is seen as a tool to ensure the sustainable management of the virgin wood supply-chain.

Table 2 highlights the increases and decreases with respect to the previous year for the same period 2010-2015 as Figure 2 and again considering 2010 as the starting year. 
TABLE 2 ABOUT HERE

Table 2 shows how EMAS did not decrease constantly in the reference years but from 2013 to 2014 it has a positive trend. After direct consultation with the company that manages the EMAS help desk and EMAS register, we were told that "strange" trends in EMAS numbers can sometimes be explained by the fact that the register has not been updated due to a late communication received from the Member States. ISO14001 and FSC in the last years reduced their yearly increases, and there was then a slight decrease for ISO14001 in 2015 compared to 2014.

These data reinforce the need to explain the decrease in EMAS, since its downward trend is anomalous compared to the other voluntary certification standards considered in our study.

\subsection{The reasons for the EMAS decrease}

As expected, our study confirms that there are different reasons explaining the decrease in EMAS registrations. Indeed, during the further examination of responses during the interviews with organisations showed that the decrease of EMAS certification can be explained by several factors. As anticipated in this section, the decrease of EMAS has been analysed under two points of view: investigating the drop out factors of EMAS, analysing why the ISO14001 certified organisations do not adopt EMAS. The interviewees gave several reasons for abandoning or not adopting the scheme. Some of the questions were not answered sufficiently clearly as many aspects of their certification experiences were covered in the interviews. We obtained 17 usable answers out of 38 total interviewed companies. The collected replies were reported in a qualitative way citing the answers received by the different environmental managers interviewed. As in EMS studies carried out by other scholars (e.g. Heras-Saizarbitoria et al., 2013) we reported the interviews in the exact form we received them from the companies, using quotation marks. The reasons for EMAS abandonment (RQ2.1) or the barriers experienced by ISO14001 organisations in the passing to EMAS (RQ2.2) are summarized in the next four sections. In particular, when in the tables of the next sections you find answers classified as from "former EMAS companies" the findings are referred to RQ2.1, when the answers are from "ISO14001 company" they support the RQ2.2.

\subsubsection{Lack of financial and human resources}

The lack of financial and human resources was one of the main drop out factor, as expected. The interviews were carried out in a period of economic crisis, and often the costs of voluntary certification were targeted in the management actions aimed at cost reductions.

The lack of time and skills in human resources was also a reason for the abandonment of EMAS. Table 3 reports the results of the interviews related to the lack of financial and human resources. The companies are also classified according to the approach of questions RQ2.1 and RQ2.2 i.e. companies that decided to abandon EMAS and ISO14001 certified companies that decide not to adopt EMAS certification.

TABLE 3 ABOUT HERE 
Table 3 shows significant issues regarding the second research question. First, the lack of financial and human resources are considered as abandonment reasons only for the SMEs in our sample.

Second, the sample only includes former EMAS companies. This means that any company with ISO 14001 certification reported that they did not decide to achieve EMAS due to costs or lack of human resources. EMAS and ISO14001 are not particularly different in terms of costs or mandatory requirements (Testa et al., 2014). All the items cited in the company statements such as costs of verifiers, data processing, reports and documents required and performance indicators are common requirements of the two standards (Daddi et al. 2011a).

These findings not only confirm the reasons for EMAS abandonment reported by other authors in the literature review (i.e. Preziosi et al., 2016) but also authors that classified these issues as barriers in the initial adoption of an EMS (i.e. Salomone, 2008). This implies that the costs for the initial adoption of EMAS are higher than the costs of maintaining it. Thus these findings reveal that although companies may have incurred relatively high costs in adopting EMAS, the subsequent lower costs were not sufficiently low to motivate them to continue with the EMAS. This confirms that the influence of the economic crisis played an important role in the reasons for abandoning the certification.

\subsubsection{Lack of market recognition}

Four large companies mentioned the lack of market recognition as a reason not adopt EMAS or to abandon it. This issue was also reported by two former EMAS companies, as well as by two ISO certified companies (Table 4).

\section{TABLE 4 ABOUT HERE}

The interviewed organisations mentioned two main issues related to market recognition: the recognition of EMAS registration by customers, and the recognition of EMAS in public tenders. The first element confirms the findings that were discussed in Section 2. The benefits of EMAS (and more in general of EMS) can range from the management of legal compliance (Iraldo et al., 2009) to resource savings (Vernon et al., 2009), from performance improvement (Daddi et al., 2011a) to administrative simplifications (Testa et al., 2016). However no study has highlighted the effective contribution of the EMS certification in terms of customer satisfaction. EMAS can be considered more as a "Busness2Business" tool than a "Business2Consumer" tool. This explains the abandonment of the large Spanish company No. 1 (see table 3), probably its expectations after the initial adoption of EMAS where not fully in line with its benefits.

The lack of recognition of EMAS in the market of public tenders i.e. in the Green Public Procurement (GPP) activities was cited by two large German companies. EMAS is a public environmental certification, established by a Regulation issued by the European Commission, and managed by a public Competent Body. It is natural to expect advantages compared to other private environmental certification such as ISO14001 in the tenders of public authorities. GPP is a relatively new area of research (Nissinen et al., 2009) and also the relation between environmental certifications and GPP has not been widely explored. Our findings contribute to this field by highlighting how the lack of recognition of EMAS in public tenders may be a reason why former EMAS registered companies go on to abandon it as well as it being a barrier to adoption by already ISO14001-certified organisations.

\subsubsection{Lack of external stakeholders recognition}


Stakeholder recognition is a key aspect of EMAS. EMAS was conceived as a tool to provide large transparency for all key stakeholders of a certified organisation, such as local communities, inspection agencies, and public authorities. The standard, as one of the additional requirement with respect to ISO14001, requires an Environmental Statement to be published and updated, where key environmental data of the organisations are available for the public (Daddi et al., 2011a). The first section of this study highlights how external stakeholders are considered as important drivers to adopting an EMS. Such drivers include greater external legitimacy (Darnall et al., 2008a) and pressure from local communities (Daddi et al., 2011b). Table 5 shows that companies are not fully convinced of the value of EMAS in enhancing their image in relation to external stakeholders.

\section{TABLE 5 ABOUT HERE}

The companies that were formerly EMAS registered and current ISO14001 companies - both large and small - agreed about the lack of external stakeholder recognition including the lack of recognition of public authorities leading to a lack of incentives and public promotion. Policy makers from different levels should promote EMAS more if they want to achieve a wider diffusion of certifications or at least to halt its decrease.

\subsubsection{Other reasons: lack of EMAS added value and sensitive data}

As highlighted in Section 2, ISO14001 is often considered as a first and intermediate step before achieving EMAS, i.e. it is considered as being at a lower level to an EMS (Testa et al., 2014). In fact the EMAS Regulation includes the standard ISO14001 in its annexes as a reference for the Management System while imposing additional requirements not foreseen in the ISO certification such as the Environmental Statement. Thus, EMAS-registered businesses feel they have adopted a tool of excellence for environmental management. This explains why they expect added value with respect to ISO14001. Table 6 shows that in one case a large German company (No. 2) did not expect this added value.

\section{TABLE 6 ABOUT HERE}

The former EMAS company (No. 1) recognised the validity of EMAS as an environmental management tool. In its opinion, the added value of EMAS is mainly related to the short-medium period. In the long run, it loses its added value and the benefits can be perceived also only maintaining the management system although if not EMAS certified. The reason given by the German SME confirms the findings highlighted in the previous two sections. EMAS provides internal benefits in the management of environmental issues but the added value of the certificate for customers or external stakeholders in this case is also considered as low.

Table 6 highlights a reason not commonly reported in previous studies. The transparency required by EMAS has been always considered as an added value of the standard and an approach to increasing the external image of companies. Many organisations, even if they are not EMAS registered, decide to publish environmental claims and reports in order to communicate their commitment in environmental or social issues to external stakeholders. This approach, which is a key aspect of EMAS, is considered by some companies as a limitation to adopting or maintaining the scheme due to the advantages that could be obtained by the competitors from the published environmental data (Table 7). 


\section{TABLE 7 ABOUT HERE}

\section{Discussion}

According to our findings, there are many drop out factors that explain EMAS abandonment. These factors are heterogeneous in nature and scope.

Firstly, our study indicates that for many companies the "maintenance" costs of EMAS have been proportionally higher than efficiency gains. In this sense, our study is in line with previous findings, as the recent survey of Merli et al. (2016) affirming that the cost of maintenance of the registration is one of the main barriers faced by EMAS organizations. It appears that the role of the "maintenance costs" vary significantly, due to the size of the organisation as well as in reference to the specific national context companies operate into. Particularly for smaller organisations, costs can still be a significant factor when deciding whether or not to leave the scheme. Given that $98 \%$ of companies in the EU are micro, small and medium-sized enterprises (Eurostat, 2012), this surely has an impact on the recent decrease in the EMAS numbers. Further strengthening EMAS's internal capability to help achieve competitive and efficiency improvements remains a challenge which must be addressed by policy makers in order to establish a clear business case for the scheme. In this sense, the study revealed that also the lack of human resources represents a key reason for the EMAS abandonment. Similarly, previous studies found that the lack of human resources is one of the main barriers for the adoption of environmental management standards (Halila, 2007; OECD, 2005).

Secondly, not only maintenance costs are to be regarded, however, as relevant. Different studies stress how even the lack of customer interest and awareness (Iraldo et al., 2006; Vernon et al., 2009) and the lack of recognition (Wätzold et al. 2001) and positive rewards by public institutions play a relevant and detrimental role, from such perspective (Von Ahsen et al, 2004).

As to the lack of recognition from the market, we can say that intangible benefits (their significance cannot be measured in monetary terms) can help provide added value to organisations. However, these benefits do not necessarily directly translate into cost efficiency gains or competitive advantages. For example, customer requests can play a crucial role as a market-based driver. In that sense, implementing an environmental management scheme can be likened to a "license to operate". For EMAS, this driver did not work as it should. In our study, interviewed organisations do not think that features such as the EMAS logo and the environmental statement, which could raise EMAS's profile and strengthen its position on the market, are currently fit for this purpose. Evidence suggests that modifying these (and additional) features could lead to a better realisation of intangible benefits. Different causes for the scarce awareness of EMAS by consumers and other market players have been identified, ranging from a lack of promotional activities at all levels (e.g: EU or governmental campaigns) to a wide "confusion", deriving from the spread of many certifications and labels overlapping with EMAS.

Thirdly, our findings identify another drop out factor in the lack of awareness of EMAS among external stakeholders. One common complaint of companies that have dropped out of EMAS is that the scheme is not widely known. As mentioned above, this lack of general recognition has additional clear consequences on both the effectiveness and the efficiency of the EMAS Regulation. Organisations experience little pressure from external sources to choose EMAS over other environmental management instruments, thus eliminating a potential distinctive advantage. Additionally, some organisations do not experience the potential tangible benefit of being more attractive for (and thus attracting more) customers and so they opt to leave the scheme.

Finally, our findings also emphasise that there are internal drop out factors making companies withdraw from EMAS. This category of drop out factors is vast and heterogeneous, ranging from lack of resources (e.g.: time and human capital, as found also by Iraldo et al., 2006) to difficulties in the 
understanding and perception of the EMAS scheme, from drawbacks in its implementation process to the culture itself of organisations, and so on. There is evidence in our qualitative study that companies face relevant hardships in effectively applying the scheme and its requirements. But the most relevant internal barrier is represented by the lack of resources, both financial and human. These assets are vital for a successful achievement and implementation of EMAS; among them we can mention, for instance, the availability of management time, or the adequacy of human resources, being these personnel with proper skills, expertise and technical background. The lack of resources can be even worsened by the high demands of documentation (both asked by the verifiers and strongly suggested by the consultants). In this case, the risk is that of focusing all (limited) resources on documentation, instead of following and developing the environmental objectives and the environmental performance. Moreover, employees in charge of the EMS might feel de-motivated believing the documentation requires too much of their time, and instead of documenting the problems, they pretend not to see them. A final internal drop out factor highlighted by our study can be defined as "indirect" and identified in the fact that the implementation of EMAS might have backlashes, for instance, by disclosing certain "sensitive information" that the companies deem confidential. This can have a strong demotivating effect on the participation in the scheme.

As we can expect many of the drop out factors are mirrored also as results linked with the RQ2.2 related to the reasons of the not adoption of EMAS by ISO14001 certified companies. These can be summarized in a key issue related to the relation/competition between EMAS and ISO14001: many organisations don't yet see a full added value in the adoption of EMAS. They perceive as a step further in the frame of Environmental Management standards, but this excellence "fights" with the lack of external stakeholders recognition such as clients, public institutions, or the higher diffusion at the international level of ISO14001.

\section{Conclusions}

Some conclusions can be drawn up from a policy makers perspective. The role played by public sector has a crucial effect on the uptake of EMAS, as a relevant drop out factor can be also represented by a "hostile" overall institutional context (with central and regional governments refusing to promote the scheme). In particular, for various features of EMAS, including environmental reporting or legal compliance checks, the added value the scheme provides is directly linked to the question of whether regulators are willing to grant support on the basis of the value provided by EMAS. This would include, for instance, regulatory relief resulting from EMAS's built-in internal checks for legal compliance. Given the findings highlighted in this study, it is clear that benefits in the form of policy support (e.g. regulatory relief, financial incentives) could create suitable framework conditions which would keep EMAS registered companies within the scheme. However, our findings indicate that there is a lack of policy support (e.g. in the form of regulatory relief or tax breaks) both at EU and at Member State level, as also confirmed by previous studies (Von Ahsen et al, 2004; Vernon et al., 2009). According to our results, the most significant barrier to a more successful implementation of the EMAS Regulation - at both levels - is the lack of consistence and recognition of EMAS in the general environmental legislative and regulatory framework.

Although the EMAS Regulation defines clear requirements on these matters, evidence indicates that neither the European Commission or the Member States are implementing support measures for EMAS either sufficiently or effectively on a regular basis. For example, the vast majority of the EMAS registered organisations surveyed emphasised that they do not experience better access to public funding or procurement procedures (including service contracts). One key question is whether this absence of policy support can be attributed purely to a lack of financial and human resources and to a lack of awareness among policy makers about the added value of EMAS, or whether a lack of trust in the effectiveness of the scheme may also play a substantial role.

From a managerial perspective, the paper contributes to solve some doubts of managers that are in front of the decision to adopt one or the other tool. Drop out factors can be considered useful 
indications for the companies that are about to start their certification process but that they would like to avoid to drop out of the scheme in the near future.

To conclude some limitations of the paper can be highlighted. Firstly, the data available are referred to a limited sample of companies and for that reason they cannot be generalized to the whole population of EMAS registered companies. In addition the European EMAS Competent Bodies don't monitor the number of EMAS abandonments so it is not possible to point out the representativeness of our interviewed sample. Also data of main sectors affected by the abandonments are not available. EMAS key players and policy makers should monitor these data in order to have more info to adopt specific policies to spread EMAS. Secondly, the Member States representativeness is mainly related to Italy and Germany with a low involvement of other countries and information about the sector has been not provided by interviewed organizations reducing the sample details available in this study. Thirdly, according to the data available it has not been possible to observe the different contribution in the EMAS decrease given by the increase of EMAS abandonments or by the decrease of EMAS new registrations.

To overcome these limitations, we invite scholars to publish future studies on this topic using large online survey enlarging the number and the geographical context of the sample. An additional future research could take into account the publication of the new EMAS Regulation. It would be interesting to analyse how the novelties of the new Regulation could address the reasons of EMAS decrease described in this paper. 


\section{References}

Arimura, H., N. Darnall, R. Ganguli, and H. Katayama. 2016. "The Effect of ISO 14001 on Environmental Performance: Resolving Equivocal Findings." Journal of Environmental Management 166: 556-566.

Barde, J.-Ph. 1995. "Environmental Policy and Instruments." In Principles of Environmental and Resource Economics, edited by Folmer, H., Gabel, L.H., Opschoor, H, 201-227. London: Edward Elgar.

Bist, M. 2007. "ISO 14001 and EMAS in Small and Medium-Sized Enterprises - Obstacles to Implement these Environmental Management Approaches in SMEs and How to Improve the Potential of these Approaches for the Usage in SMEs." The IMRE Journal 1 (2): 1-10.

Boiral, O. 2011. "Managing with ISO Systems: Lessons from Practice." Long Range Planning 44 (3): 197-220.

Bracke, R., and J. Albrecht. 2007. "Competing Environmental Management Standards: How ISO 14001 Outnumbered EMAS in Germany, the UK, France, and Sweden." Environment and Planning C: Government and Policy 25 (4): 611-627.

Burnard, P. 1994. "The Telephone Interview as a Data Collection Method." Nurse Education Today 14 (1): 67-72.

Casadesus, M., F. Marimon, and I. Heras. 2008. "ISO 14001 Diffusion After the Success of the ISO 9001 Model". Journal of Cleaner Production 16 (16): 1741-1754.

Daddi T., Testa F., Iraldo F., (2010) "A cluster-based approach as an effective way to implement the ECAP (Environmental Compliance Action Program): evidence from some good practices" Local Environment 15(1), 73-82

Daddi, T., M. Magistrelli, M. Frey, and F. Iraldo. 2011a. "Do Environmental Management Systems Improve Environmental Performance? Empirical Evidence from Italian Companies." Environment, Development, Sustainability 13(5): 845-862

Daddi, T., M. Frey, F. Iraldo, and B. Nabil. 2011b. "The Implementation of an Environmental Management System in a North-African Local Public Administration: the Case of the City Council of Marrakech (Morocco)". Journal of Environmental Planning and Management 54 (6): 813-832.

Daddi, T., F. Testa, F. Iraldo and M. Frey. 2014. "Removing and Simplifying Administrative Costs and Burdens for EMAS and ISO 14001 Certified Organizations: Evidences from Italy." Environmental Engineering and Management Journal 13 (3): 689-698.

Daddi, T., M.R. De Giacomo, F. Testa, M. Frey, and F. Iraldo. 2014. "The Effects of Integrated Pollution Prevention and Control (IPPC) Regulation on Companies Management and Competitiveness." Business Strategy and the Environment 23 (8): 520-533.

Daddi, T., M.R. De Giacomo, F. Testa, M. Frey, and F. Iraldo. 2015. "Macro-Economic and Development Indexes and ISO14001 Certificates: a Cross National Analysis." Journal of Cleaner Production 108 (Part A): 1239-1248.

Daddi T., Iraldo F., (2016). The effectiveness of cluster approach to improve environmental corporate performance in an industrial district of SMEs: a case study. International Journal of Sustainable Development \& World Ecology, 23(2), 163-173.

Daddi, T., F. Iraldo F, M. Frey, P. Gallo, and V. Gianfrate. 2016a. "Regional Policies and Ecoindustrial Development: the Voluntary Environmental Certification Scheme of the Eco-industrial Parks in Tuscany (Italy)." Journal of Cleaner Production 114: 62-70.

Daddi, T., F. Testa, M. Frey, and F. Iraldo. 2016b. "Exploring the Link Between Institutional Pressures and Environmental Management Systems Effectiveness: an Empirical Study." Journal of Environmental Management 183 (3): 647-656.

Darnall, N., I. Henriques, and P. Sadorsky. 2008b. "Do Environmental Management Systems Improve Business Performance in an International Setting?" Journal of International Management 14 (4): 364-376. 
Darnall, N., G. Jason Jolley, and R. Handfield. 2008a. "Environmental Management Systems and Green Supply Chain Management: Complements for Sustainability?" Business Strategy and the Environment 17 (1): 30-45.

EU EMAS Register (Accessed 25 November, 2016): http://ec.europa.eu/environment/emas/register/. EUROSTAT, (2012), Key figures on Europe 2012, European Commission, Luxembourg, On line at: http://epp.eurostat.ec.europa.eu/cache/ITY_OFFPUB/ KS-EI-12-001/EN/KS-EI-12-001-EN.PDF

Feng, T., G. Zhao, and K. Su. 2014. "The Fit Between Environmental Management Systems and Organisational Learning Orientation." International Journal of Production Research 52 (10): 2901-2914.

FSC, 2015a. Market Info Pack: an Overview of Recent Trends and Current Status of FSC Certification, (June 2015).

FSC, 2015b. FSC. Facts and Figures. (Accessed 25 November, 2016): https://ic.fsc.org/preview.facts-figures-december-2015.a-5253.pdf

Grolleau, G., N. Mzoughi, and A. Thomas. 2007. "What Drives Agrifood Firms to Register for an Environmental Management System?” European Review of Agricultural Economics 34 (2): 233255.

Halila, F., 2007. Networks as a means of supporting the adoption of organizational innovations in SMEs: the case of Environmental Management Systems (EMSs) based on ISO 14001. Corporate Social Responsibility and Environmental Management 14: 167-181.

Hawkins, R. 2000. "Use of Economic Instruments and Green Taxes to Complement an Environmental Regulatory Regime." Water, Air, and Soil Pollution 123: 379-394.

Heras-Saizarbitoria, I., K. Dogui, and O. Boiral. 2013. "Shedding Light on ISO 14001 Certification Audits." Journal of Cleaner Production 51: 88-98.

Heras-Saizarbitoria, I., G. Arana, and O. Boiral O. 2015a. "Exploring the Dissemination of Environmental Certifications in High and Low Polluting Industries." Journal of Cleaner Production 89: 50-58.

Heras-Saizarbitoria, I., O. Boiral, and G. Arana. 2015b. "Renewing Environmental Certification in Times of Crisis." Journal of Cleaner Production 115: 214-223.

Hillary, R. 2004. "Environmental Management Systems and the Smaller Enterprise." Journal of Cleaner Production 12 (6): 561-569.

Iraldo, F., F. Testa, and M. Frey. 2009. "Is an Environmental Management System Able to Influence Environmental and Competitive Performance? The Case of the Eco-Management and Audit Scheme (EMAS) in the European Union." Journal of Cleaner Production 17 (16): 1444-1452.

Iraldo, F., P., Lanzini, M. Melis, W. Kahlenborn, I. Freier, F. Rubik, K. Ankele., D. Scheer, J. Hertin, J.M. Garcia, A. Scott, B. Nielsen, and A. Petersen, 2006. EVER: Evaluation of EMAS and EcoLabel for their Revision. Research Findings. Final report by IEFE, Bocconi, adelphi consult, IOEW, SPRU, Valor \&Tinge to the European Commission, Part I-II. Brussels: European Commission.

ISO, 2015. "The ISO Survey of Management System Standard Certifications". Accessed January 2 2016. http://www.iso.org/iso/iso-survey.

Lagodimos, A.G., P.T. Chountalas, and K. Chatzi. 2007. "The State of ISO 14001 Certification in Greece." Journal of Cleaner Production 15 (18): 1743-1754.

Lozano, M., and J. Vallés. 2007. "An Analysis of the Implementation of an Environmental Management System in a Local Public Administration." Journal of Environmental Management 82 (4): 495-511.

Maiello, A., Battaglia, M., Daddi, T., and M. Frey. 2011. "Urban sustainability and knowledge: Theoretical heterogeneity and the need of a transdisciplinary framework. A tale of four towns" Futures, 43, 1164-1174

Marimon, F., J. Llack, and M. Bernardo. 2011. "Comparative Analysis of Diffusion of the ISO 14001 Standard by Sector of Activity.” Journal of Cleaner Production 19 (15): 1734-1744. 
Martín-Peña, M.L., E. Díaz-Garrido, and J.M. Sánchez-López. 2014. "Analysis of Benefits and Difficulties Associated with Firms' Environmental Management Systems: the Case of the Spanish Automotive Industry." Journal of Cleaner Production 70 (1): 220-230.

Melnyk, S.A., R.P. Sroufe, and R. Calantone. 2003. "Assessing the Impact of Environmental Management Systems on Corporate and Environmental Performance." Journal of Operations Management 21 (3): 329-351.

Merli, R., M. Preziosi, and C. Ippolito. 2016. "Promoting sustainability through EMS application: a survey examining the critical factors about EMAS registration on Italian organizations". Sustainability 8 (3): 1-14.

Neugebauer, F. 2012. "EMAS and ISO 14001 in the German Industry - Complements or Substitutes?" Journal of Cleaner Production 37: 249-256.

Nissinen, A., K. Parikka-Alholaa, and H. Ritab. 2009. "Environmental Criteria in the Public Purchases Above the EU Threshold Values by Three Nordic Countries: 2003 and 2005." Ecological Economics 68 (6): 1838-1849

Northern Ireland Environment Agency, 2009. Measuring the Effectiveness of Environmental Management Systems. Final Report, Ireland. Phase 1: Desktop Report, June 2009.

OECD, 2005. Oslo Manual. Guidelines for collecting and interpreting innovation data. Third edition.

Patton, M. Q. 2002. Qualitative Research and Evaluation Methods 3rd ed. Thousand Oaks, CA: Sage.

Prakash, A., and M. Potoski. 2006. "Racing to the Bottom? Trade, Environmental Governance, and ISO 14001." American Journal of Political Science 50 (2): 347-361

Preziosi, M., R. Merli, and M. D’Amico. 2016. "Why Companies Do not Renew Their EMAS Registration? An Exploratory Research.” Sustainability 8 (2): 1-11.

Ryan, F., M. Coughlan, and P. Cronin. 2009. "Interviewing in Qualitative Research: The One-to-One Interview." International Journal of Therapy and Rehabilitation 16 (6): 309-314.

Salomone, R. 2008. "Integrated Management Systems: Experiences in Italian Organisations." Journal of Cleaner Production 16 (16): 1786-1806.

Sambasivan, M., andN.Y. Fei. 2008. "Evaluation of Critical Success Factors of Implementation of ISO 14001 Using Analytic Hierarchy Process (AHP): a Case Study From Malaysia.” Journal of Cleaner Production 16 (13): 1424-1433.

Sayre, D. 1996. Inside ISO 14001: The Competitive Advantage of Environmental Management. Delray Beach, FL: St. Lucie Press.

Seidman, I. 1998. Interviewing as Qualitative Research: A Guide for Researchers in Education and the Social Sciences. New York: Teachers College Press.

Stevens, P.A., W.J. Batty, P.J. Longhurst, and G.H Drew. 2012. "A Critical Review of Classification of Organisations in Relation to the Voluntary Implementation of Environmental Management Systems." Journal of Environmental Management 113: 206-212.

Testa, F., F. Iraldo, and M. Frey, M. 2011. "The Effect of Environmental Regulation on Firms' Competitive Performance: The Case of the Building and Construction Sector in Some EU Regions." Journal of Environmental Management 92 (9): 2136-2144.

Testa, F., O. Boiral, and F. Iraldo. 2015. "Internalization of Environmental Practices and Institutional Complexity: Can Stakeholders Pressures Encourage Greenwashing?” Journal of Business Ethics: $1-21$.

Testa, F., T. Daddi, M.R. De Giacomo, F. Iraldo, and M. Frey. 2014. "The Effect of IPPC Regulation on Facility Performance." Journal of Cleaner Production 64: 91-97.

Testa, F., I. Heras-Saizarbitoria, T. Daddi, T, O. Boiral, and F. Iraldo. 2016. "Public Regulatory Relief and the Adoption of Environmental Management Systems: a European Survey." Journal of Environmental Planning and Management: 1-20.

Testa, F., F. Rizzi, T. Daddi, T, N.M. Gusmerotti, M. Frey, and F. Iraldo. 2014. "EMAS and ISO 14001: the Differences in Effectively Improving Environmental Performance." Journal of Cleaner Production 68: 165-173. 
To, W.M., and P.K.C. Lee. 2012. "Diffusion of ISO 14001 Environmental Management System: Global, Regional and Country-Level Analyses." Journal of Cleaner Production 66: 489-498.

UBA and BMU. 2013. German Federal Environment Agency (UBA), German Federal Ministry for the Environment, Nature Conservation and Nuclear Safety (BMU). EMAS in Germany Evaluation 2012, $1^{\text {st }}$ edition.

Vernon, J., M. Peacoc, A. Belin, C. Ganzleben, and M. Candell. 2009. Study on the Costs and Benefits of EMAS to Registered Organisations. European Commission Final Report by Milieu Ltd. and RPA Ltd, Brussels, Belgium; Risk and Policy Analysis Ltd: London, UK.

Von Ahsen, A., C. Lange, M. Pianowski. 2004. "Corporate Environmental Reporting: Survey and Empirical Evidence.” International Journal of Environment and Sustainable Development 3 (1): 5-17.

Wätzold, R., A. Bültmann, M. Eames, K. Lulofs, and S. Schucht: 2001. EMAS and Regulatory Relief in Europe: Lessons from National Experience. In: Environmental Policy and Governance 11 (1): 3749.

Weber, R.P. 1990. Basic Content Analysis. 2nd ed. Newbury Park, CA: Sage.

Weiss, D, A. Skinner, M. Smyth, M. Slupska, W. Kahlenborn, F. Iraldo, T. Daddi, M.R. De Giacomo, F. Testa, M. Melis, adelphi consult GmbH, Berlin, Germany and S. Anna University, Pisa, Italy, Germany June 2015. Final Report. Supporting the Evaluation of the Implementation of EMAS, European Commission, Directorate-General for the Environment, 2017. 


\section{TABLES}

\begin{tabular}{c|c|c}
$\mathbf{N}$. & Dimension & Country \\
\hline $\mathbf{4}$ & SME & Germany \\
\hline $\mathbf{2}$ & SME & Italy \\
\hline $\mathbf{1}$ & SME & Estonia \\
\hline $\mathbf{1}$ & Large & Bulgaria \\
\hline $\mathbf{4}$ & Large & Germany \\
\hline $\mathbf{1}$ & Large & Italy \\
\hline $\mathbf{3}$ & Large & Spain \\
\hline $\mathbf{1}$ & anonymous & anonymous \\
\hline & Total: $\mathbf{1 7}$ \\
\hline
\end{tabular}

Table 1. Sample description 


\begin{tabular}{|c|c|c|c|c|c|c|}
\hline Year & 2010 & 2011 & 2012 & 2013 & 2014 & 2015 \\
\hline \multirow{2}{*}{ ISO 14001 } & & $-1,6 \%$ & $10 \%$ & $3,7 \%$ & $2 \%$ & $-0,4 \%$ \\
\cline { 2 - 6 } EMAS & & $-0,2 \%$ & $-1,4 \%$ & $-16,8 \%$ & $8,1 \%$ & $-2,4 \%$ \\
\hline FSC & & $21,7 \%$ & $15 \%$ & $17,5 \%$ & $5 \%$ & $6,3 \%$ \\
\hline
\end{tabular}

Table 2. Percentage variation in the number of certifications (2010-2015) 


\begin{tabular}{|c|c|c|c|}
\hline N. & $\begin{array}{l}\text { Kind of } \\
\text { company }\end{array}$ & Sample & Company's statement \\
\hline 1 & German SME & $\begin{array}{l}\square \text { Former EMAS company } \\
\square \text { ISO14001 company }\end{array}$ & $\begin{array}{l}\text { "My company is small and costs to pay for the } \\
\text { EMAS certification are too high. For example, } \\
\text { costs for the environmental verifiers were } \\
\text { constraining for us" }\end{array}$ \\
\hline 2 & Italian SME & $\begin{array}{l}\square \text { Former EMAS company } \\
\square \text { ISO14001 company }\end{array}$ & $\begin{array}{l}\text { "Costs to maintain EMAS were problematic } \\
\text { issues for our company" }\end{array}$ \\
\hline 3 & Italian SME & $\begin{array}{l}\text { ■ Former EMAS company } \\
\square \text { ISO14001 company }\end{array}$ & $\begin{array}{l}\text { "The time to manage the certification were } \\
\text { problematic issues. The processing of data was } \\
\text { time consuming, as also the carrying out of } \\
\text { documents as the Environmental Statement" }\end{array}$ \\
\hline 4 & German SME & $\begin{array}{l}\square \text { Former EMAS company } \\
\square \text { ISO14001 company }\end{array}$ & $\begin{array}{l}\text { "We left the EMAS because the needed report } \\
\text { and documents required us a too high staff } \\
\text { effort and we are a small company with limited } \\
\text { human resources" }\end{array}$ \\
\hline 5 & German SME & $\begin{array}{l}\square \text { Former EMAS company } \\
\square \text { ISO14001 company }\end{array}$ & $\begin{array}{l}\text { "We faced limits and problems with EMAS in } \\
\text { order to achieve specific objectives and } \\
\text { environmental targets. Meet EMAS } \\
\text { requirements on core environmental indicators } \\
\text { was also very difficult for us" }\end{array}$ \\
\hline
\end{tabular}

Table 3. Interviews results related to the lack of financial and human resources 


\begin{tabular}{|c|c|c|c|}
\hline N. & $\begin{array}{l}\text { Kind of } \\
\text { company }\end{array}$ & Sample & Company's statement \\
\hline 1 & $\begin{array}{l}\text { Large Spanish } \\
\text { company }\end{array}$ & $\begin{array}{l}\square \text { Former EMAS company } \\
\square \text { ISO14001 company }\end{array}$ & $\begin{array}{l}\text { "The decision to maintain only ISO } 14001 \text { and } \\
\text { to abandon was due to the higher knowledge } \\
\text { and acceptance of this standard by customers. } \\
\text { They know more the ISO } 14001 \text { certification } \\
\text { than EMAS and keeping both standard would } \\
\text { require a great deal effort" }\end{array}$ \\
\hline 2 & $\begin{array}{l}\text { Large German } \\
\text { company }\end{array}$ & $\begin{array}{l}\text { ■ Former EMAS company } \\
\square \text { ISO14001 company }\end{array}$ & $\begin{array}{l}\text { "One of the reasons that has encouraged my } \\
\text { company to leave the EMAS scheme is that it } \\
\text { not represents a valid tool to win public } \\
\text { tenders. In this sense, EMAS did not bring us } \\
\text { any added value in Green Public Procurement } \\
\text { procedures that was our main driver when we } \\
\text { decided to adopt it" }\end{array}$ \\
\hline 3 & $\begin{array}{l}\text { Large Spanish } \\
\text { company }\end{array}$ & $\begin{array}{l}\square \text { Former EMAS company } \\
\square \text { ISO14001 company }\end{array}$ & $\begin{array}{l}\text { "EMAS is mainly recognized within Europe. } \\
\text { We are a large company and we sell our } \\
\text { products around many countries in Asia and in } \\
\text { the United States, where EMAS cannot be } \\
\text { valorised toward customers. On the contrary, } \\
\text { the ISO } 14001 \text { environmental certification is a } \\
\text { worldwide scheme, known in all countries. For } \\
\text { this reason we keep only ISO } 14001 \text { without } \\
\text { pass to EMAS" }\end{array}$ \\
\hline 4 & $\begin{array}{l}\text { Large German } \\
\text { company }\end{array}$ & $\begin{array}{l}\square \text { Former EMAS company } \\
\square \text { ISO14001 company }\end{array}$ & $\begin{array}{l}\text { "EMAS does not provide any additional } \\
\text { advantages in public procurement or in } \\
\text { obtaining contracts. As international company, } \\
\text { it is substantially easier to have a global } \\
\text { environmental standard rather than one that is } \\
\text { only used in Europe" }\end{array}$ \\
\hline
\end{tabular}

Table 4. Interviews results related to the topic lack of market recognition 


\begin{tabular}{|c|c|c|c|}
\hline $\mathbf{N}$. & $\begin{array}{l}\text { Kind of } \\
\text { company }\end{array}$ & Sample & Company's statement \\
\hline 1 & Anonymous & $\begin{array}{l}\square \text { Former EMAS company } \\
\square \text { ISO14001 company }\end{array}$ & $\begin{array}{l}\text { "We left EMAS because our public } \\
\text { stakeholders do not demonstrate engagement } \\
\text { with the scheme. Local, political and public } \\
\text { actors are not interested in EMAS and they not } \\
\text { promote it" }\end{array}$ \\
\hline 2 & $\begin{array}{l}\text { Large Spanish } \\
\text { company }\end{array}$ & $\begin{array}{l}\square \text { Former EMAS company } \\
\square \text { ISO14001 company }\end{array}$ & $\begin{array}{l}\text { "When my company decided to implement an } \\
\text { Environmental Management System we } \\
\text { preferred the ISO } 14001 \text { standard to EMAS. In } \\
\text { fact, we noted that EMAS is very few recognised } \\
\text { by our key stakeholders as clients and public } \\
\text { actors" }\end{array}$ \\
\hline 3 & $\begin{array}{c}\text { Large } \\
\text { Bulgarian } \\
\text { company }\end{array}$ & $\begin{array}{l}\square \text { Former EMAS company } \\
\square \text { ISO14001 company }\end{array}$ & $\begin{array}{l}\text { "The main barriers that prevented our } \\
\text { organization to go for EMAS registration are } \\
\text { the lack of external incentives, the overall lack } \\
\text { of recognition of the scheme by stakeholders, } \\
\text { customers, market, public authorities, and } \\
\text { internationally" }\end{array}$ \\
\hline 4 & Estonian SME & $\begin{array}{l}\square \text { Former EMAS company } \\
\square \text { ISO14001 company }\end{array}$ & $\begin{array}{l}\text { "The lack of external incentives, lack of EMAS } \\
\text { recognition among stakeholders and customers } \\
\text { and lack of recognition by public organisations } \\
\text { also at the international level represent the } \\
\text { main reasons for not implementing EMAS" }\end{array}$ \\
\hline
\end{tabular}

Table 5. Interviews results related to the lack of external stakeholders recognition 


\begin{tabular}{|c|c|c|c|}
\hline $\mathbf{N}$. & $\begin{array}{c}\text { Kind of } \\
\text { company }\end{array}$ & Sample & Company's statement \\
\hline 1 & German SME & $\begin{array}{l}\square \text { Former EMAS company } \\
\square \text { ISO14001 company }\end{array}$ & $\begin{array}{l}\text { "Our organisation has been registered EMAS } \\
\text { for } 8 \text { years. After these years, the environmental } \\
\text { management of our company has benefited a lot } \\
\text { but in the last years, the registration is not } \\
\text { giving any more added value as at the } \\
\text { beginning. So we decided to maintain the } \\
\text { structured Management System but to abandon } \\
\text { the EMAS registration" }\end{array}$ \\
\hline 2 & $\begin{array}{l}\text { Large German } \\
\text { company }\end{array}$ & $\begin{array}{l}\square \text { Former EMAS company } \\
\square \text { ISO14001 company }\end{array}$ & $\begin{array}{l}\text { "EMAS does not provide any additional value } \\
\text { over an ISO14001 certification that would } \\
\text { compensate for substantial additional effort } \\
\text { and expense involved in EMAS verification. The } \\
\text { regulatory relief is only marginal for our } \\
\text { organisation while individual daughter } \\
\text { companies are much more familiar with } \\
\text { ISO14001 than they are with EMAS" }\end{array}$ \\
\hline
\end{tabular}

Table 6. Interviews results related to the topic lack of EMAS added value 


\begin{tabular}{|c|c|c|c|}
\hline $\mathbf{N}$. & $\begin{array}{l}\text { Kind of } \\
\text { company }\end{array}$ & Sample & Company's statement \\
\hline 1 & $\begin{array}{l}\text { Large German } \\
\text { company }\end{array}$ & $\begin{array}{l}\square \text { Former EMAS company } \\
\square \text { ISO14001 company }\end{array}$ & $\begin{array}{l}\text { "We abandoned EMAS because core indicators } \\
\text { require to publish sensitive company } \\
\text { information which we, as a company, were not } \\
\text { prepared to share out for reasons of } \\
\text { competition. This was the motivation for which } \\
\text { we decided to adopt other schemes as ISO } \\
14001 \text {, but also additional certifications as ISO } \\
9001 \text { and OHSAS 18001" }\end{array}$ \\
\hline 2 & $\begin{array}{l}\text { Italian large } \\
\text { company }\end{array}$ & $\begin{array}{l}\square \text { Former EMAS company } \\
\square \text { ISO14001 company }\end{array}$ & $\begin{array}{l}\text { "The main reason because we will not apply } \\
\text { EMAS is the need to make available our data. } \\
\text { This reason is to link to the need to not make } \\
\text { available to our competitors environmental } \\
\text { data that can disseminate our industrial } \\
\text { knowledge. This is a decision taken in the } \\
\text { international Board of the company and not } \\
\text { strictly related to the Italian sites" }\end{array}$ \\
\hline
\end{tabular}

Table 7. Interviews results related to the sensitive data 